\title{
Determination of certain metals in beebread from different districts in Alexandria and El-Beheira governorates
}

\author{
Mohamed E. M. Esmael -Magda H. A. Salem - Mohamed S. E. Mahgoub- Nabil S. S. El-Barbary \\ Department of Applied Entomology- Faculty of Agriculture- Alexandria University \\ Corresponding author: dhammr@yahoo.com
}

\begin{abstract}
The present study was carried out to determine the contents of 8 metals (iron, zinc, manganese, copper, lead, chromium, arsenic and cadmium) in 12 beebread samples collected from different districts in Alexandria and ElBehaiera governorates throughout the period from March to September 2013. The obtained data showed that each of chromium (Cr) and arsenic (As) are not detected. In all districts elements could be ranked in the following descending order: $\mathrm{Fe}>\mathrm{Zn}>\mathrm{Mn}>\mathrm{Cu}>\mathrm{Pb}>\mathrm{Cd}$.

The highest and lowest levels of the studied metals in beebread samples were recorded (as ppm.) in different districts as follows:

- For iron the highest was in Etay- El baroud (167.36) and the lowest was in Al-Muntazah (61.06).

- For zinc the highest was in Abu-Hommoss (124.93) and the lowest was in El-Tabya (21.95).

- For copper the highest was in Kafr-El dawar (21.15) and the lowest was Al-Muntazah (3.12).

- For Manganese the highest was in Edko (44.87) and the lowest was was in Kafr-El dawar (13.02).

- For lead the highest was in Kafr El-Dawar (3.57) and the lowest in Etay- El baroud (0.95).

- For Cadmium the highest was in Kafr-El Dawar (1.12) the lowest in Khorshid (0.120).

All the recorded values of lead exceeded the Polish permissible slandered $(0.4 / 0.51 \mathrm{ppm})$, the Finland accepted levels of lead in food $(0.3 \mathrm{ppm})$ and also, the national accepted limits in similar products $(1.0 \mathrm{ppm})$ in Romania except the samples from Abu-Hommoss, Al-Muntazah and al-Delengat which recorded mean values 0.22, 0.23 and $0.25 \mathrm{pp}$, respectively. also, the mean value of cadmium was $0.51 \mathrm{ppm}$ that exceeded the Polish permissible slandered and Trade Norms $(0.05 \mathrm{ppm})$ and also, the Finland Norms and Kenya Bureau of Standard limits in food products (0.1 ppm).

Significant positive correlations had detected between cadmium and lead on pollen $(\mathrm{r}=0.387)$, cadmium and copper $(r=0.442)$, lead and copper $(r=0.354)$ and zinc and iron $(r=0.041)$. Negative unsignificant correlations had detected between cadmium and manganese $(r=-0.219)$, cadmium and Iron $(r=-0.150)$, lead and each of zink, manganese and iron $(r=-0.301,-0.253$ and -0.150 , respectively). In addition, negative insignificant correlations had detected between manganese and copper $(r=-0.316)$ and between iron and copper $(r=-0.114)$.

The Daily Intake metals (DIM) of Iron (10 - $60 \mathrm{mg} /$ day), zinc $(15 \mathrm{mg} / \mathrm{kg} / \mathrm{day})$, copper $(2-3 \mathrm{mg} / \mathrm{kg} / \mathrm{day})$ and Manganese $(0.5-5 \mathrm{mg} /$ day $)$ in the recommended human pollen diet $(3.66 \mathrm{mg} /$ diet $)$. These values are lower than the permissible limit which recommended by World Health Organization (WHO, 1994).
\end{abstract}

Keywords: Beebread, heavy metals, Apis mellifera, Honeybee

\section{Introduction}

Pollution is the contamination of the environment by any agent (chemical, biological or physical) that modifies the natural characteristics of the atmosphere. In Egypt and most countries, pollution by chemicals and heavy metals were known as a distinct problems only in 10 to 20 years ago (Moussa and Abdelkhalek, 2007). One of the alternative approaches is the use of biological indicators to demonstrate the environmental pollution. Insects were used as bio-indicator in terrestrial ecosystem pollution (Iqra et. al.2015; Osman et. al.2015). Honeybee Apis mellifera L. seems to be a good test insect of pesticide and heavy metal pollution (Celli, 1984; Jones, 1987; Rashed et. al.,
2009; Roman, 2010 and Van der Steean et. al., 2012). Also, honey bee products used as indicators for environmental pollution in many countries (Jablonski et al., 1995; Leita et al., 1996; Conti, 2000; Fakhimzadeh and Lodenius, 2000 a \& b; Przybyłowski and Wilczyńska, 2001; Conti and Botrè, 2001; Demirezen and Aksoy, 2005; Erbilir and Erdoĝrul, 2005; Freds \&Montenegro, 2006; Frias et. al., 2008; Mbir et. al., 2011; Perugini et. al. 2011and Shair \& Taher, 2012). Beebreed as honey bee product is a useful indicator of pollution, so many investigations on determination of the heavy metals (e.g Fe - $\mathrm{Zn}-\mathrm{Cu}-\mathrm{As}-\mathrm{Cd}-\mathrm{Cr}-\mathrm{Pb}-\mathrm{Mn}-\mathrm{Se}$ ) in beebread were carried out (Bahreyni et al., 2006; Harmanescu et al., 2007; Szczêsna, 2007; Campos 
et al., 2008; Roman, 2009; Morgano et al., 2010; Popescu et al., 2010; Moroń et al., 2011; Anđelković et al., 2012; Dima et al., 2012; Iannotti et al., 2012; Lambert et al., 2012; Marco et al., 2012; Morgano et al., 2012; Silva et al., 2012; VincevicaGaile et al., 2012; Al Naggar et al., 2013 and Formicki et al., 2013).

The aim of this study is to analyze the beebread (stored pollen) samples, collected from 12 apiaries situated at different districts in Alexandria and ElBeheira governorates from March - September 2013; for determination of the environmental pollution with certain metals ( $\mathrm{Fe}, \mathrm{Zn}, \mathrm{Cu}, \mathrm{Mn}, \mathrm{Pb}, \mathrm{Cd}$, As and $\mathrm{Cr}$ ).

\section{Materials and methods}

\section{1- Sample collecting:}

The pollen samples (beebread) were collected during the period from March to September 2013 from 12 apiaries situated at different districts of Alexandria and El-Beheira governorates (Edko, El-Delengat, AbuHommoss, Etay El-Barud, Kafr El-Dawwar, HawshEissa, El-Tarh, Abis, Al-Tabia, Khorshid, AlMuntazah, Ezbet-Mohsen.

Pollen samples were collected by cutting a piece of comb approximately 4 inch containing beebread (in both sides of the comb) by a disposable plastic knife. The samples were stored in plastic bags and kept in freezer at $-20^{\circ} \mathrm{C}$ until use. The pollen were removed by breaking the comb, and then dried overnight at $105^{\circ} \mathrm{C}$. After that the samples stored at refrigerator temperature till the time of analysis.

\section{2- Sample preparation:}

The certain metals analysis of beebread samples were carried out in Water and Soil Department, Faculty of Agriculture, El-Shatby, Alexandria University by using dry ashing technique (Issac and Kerber, 1971). One gram of sample in a crucible was placed in a preheated muffle furnace at $200-250{ }^{\circ} \mathrm{C}$ for $30 \mathrm{~min}$, and then cooled down. Five $\mathrm{ml}$ of $6 \mathrm{~N}$ HNO3 (nitric acid solution) was added. The solution was filtered through Whatman filter paper No.42 and $<0.45 \mu \mathrm{m}$ Millipore filter paper, then transferred quantitatively to a $25 \mathrm{ml}$ volumetric flask by adding distilled water. The total heavy metals contents determination by flame atomic absorption spectrometry (F-AAS) with highresolution continuum source. Eight metals were quantified for each pollen samples: Iron (Fe), Zinc $(\mathrm{Zn})$, Copper $(\mathrm{Cu})$, Manganese $(\mathrm{Mn})$, Lead $(\mathrm{Pb})$, Cadmium (Cd), Arsenic (As) and Chromium (Cr).

\section{3- Instrument:}

Analysis of heavy metals was made with Varian, spectra AA-220, Analytic-Jena device, by Flame atomic absorption spectrometry (F-AAS) in air/acetylene flame. The device working parameters (air, acetylene, optics and electronics) were adjusted for maximum absorption for each element. Acetylene was of $99.99 \%$ purity. Under the optimum established parameters, standard calibration curves for metals were constructed by plotting absorbency against concentration.

In Egypt, there were not established maximum permitted levels for the elements featuring toxic properties (heavy metals) in bee pollen. Data of all pollen samples were evaluated and compared with those of Polish Norm PN-R-78893:1997, Trade Norm BN-89/9161-06:1989, Finland Norm (Fakhimzadeh and Lodenius, 2000b). Pollen composition and standardization by Campos et al. (2008), maximum national limits accepted for heavy metals in similar product excerpt Romanian Ministry of Public Health Ordinance No. 975/1998 (Ordinance no. 975, 1998), Kenya Bureau Standards (1996),

\section{4- Calculation of daily oral intake of metals from pollen:}

The estimation of daily oral intake was calculated according to Cui et al. (2004) as follow:

Daily Intake of Metals (DIM) = daily pollen consumption $x$ average of metal concentration in pollen (mg/day).

The recommended amount of bee pollen in human daily diet must be about $36 \mathrm{~g}$ (about 4 teaspoons); it would supply the body with every vital nutrient necessary to sustain life. Pollen is usually taken 3 times a day before eating (Komosinska-Vassev, 2015). The calculated values were compared with the standards of WHO, 1994 and USAEPA, 2010.

\section{5- Statistical analysis:}

The F-test was applied for analysis of variance. L.S.D., was used to determine the significant differences. Data were analyzed according to analysis of variance procedure using Mstat-C Package (1989).

\section{Results and Discussion}

The purpose of investigation was to estimate the levels of contamination with heavy metals, i.e (Iron $(\mathrm{Fe})$, Zinc (Zn), Copper (Cu), Manganese (Mn), Lead $(\mathrm{Pb})$, Cadmium (Cd), Arsenic (As) and Chromium $(\mathrm{Cr})$ ) in beebread samples collected from 12 apiaries from Alexandria and El- Behaira Governorates during the period from March to September 2013.

Data presented in Table (1) showed that both chromium (Cr) and arsenic (As) in the present study were not detected by the applied method. Regardless of collection regions, data in Table (1) illustrated that iron (Fe) recorded the highest concentrations in all tested samples. It accounted as much as $57.5 \%$ of total 
content of minerals determined in the samples, its values ranged between 51.59 and $184.92 \mathrm{ppm}$, with an average content value of $101.65 \mathrm{ppm}$. The largest values of iron were comparable with Yossef $\boldsymbol{e t}$ al. (1978), who found that pollen relatively high in iron in Giza, Egypt. Zinc (Zn) followed iron with mean percent $23.96 \%$, its values ranged from 18.23 to 130.21 ppm with an average value of $42.36 \mathrm{ppm}$. The third largest content percentage was Manganese (Mn) $(12.54 \%)$, followed by Copper $(\mathrm{Cu})$ with $5 \%$. The $\mathrm{Mn}$ values ranged from $10.66 \mathrm{ppm}$ to $46.46 \mathrm{ppm}$ with mean value of $22.18 \mathrm{ppm}$. The concentration of $\mathrm{Cu}$ represented a moderate values ranged between 3.05 and $21.43 \mathrm{ppm}$ with mean value of $8.83 \mathrm{ppm}$. The remaining elements: $\mathrm{Pb}$ and $\mathrm{Cd}$ were observed in very low concentrations and accounted jointly for about $0.99 \%$ of the total analyzed samples. $\mathrm{Pb}$ values ranged between 0.16 and $4.05 \mathrm{ppm}$ with an average value of $1.24 \mathrm{ppm}$. While, Cd ranged from 0.09 to $1.87 \mathrm{ppm}$ with a mean value of $0.51 \mathrm{ppm}$. With respect to their content in pollen, elements could be ranked in the following descending order: $\mathrm{Fe}>\mathrm{Zn}>\mathrm{Mn}>\mathrm{Cu}>\mathrm{Pb}>$ Cd.

The most dispersed mineral values were those recorded for $\mathrm{Fe}$ with variance reached $1099.94 \mathrm{ppm}^{2}$, followed by zinc with variance value $738.99 \mathrm{ppm}^{2}$. Whereas, the least dispersed mineral content values were those for $\mathrm{Cd}\left(0.124 \mathrm{ppm}^{2}\right)$. Other measured minerals showed much dimensioned variations. Both of $\mathrm{Fe}$ and $\mathrm{Zn}$ showed the largest mean fluctuation with standard error values of \pm 5.528 and $\pm 4.531 \mathrm{ppm}$, respectively. Meanwhile, the other measured metals showed a much diminished standard error.

Table 1. Minimum, Maximum, mean variance and standard error for the measured minerals in beebread over different locations (mg. $\mathrm{kg}^{-1}$ dry mass):

\begin{tabular}{|c|c|c|c|c|c|}
\hline Mineral & $\begin{array}{l}\text { Minimum } \\
(p p m)\end{array}$ & $\begin{array}{l}\text { Maximum } \\
(p p m)\end{array}$ & $\begin{array}{l}\text { Mean } \\
(p p m)\end{array}$ & Variance & Standard error \\
\hline $\mathbf{F e}$ & 51.598 & 184.916 & 101.650 & 1099.990 & \pm 5.528 \\
\hline Zn & 18.230 & 130.214 & 42.359 & 738.9933 & \pm 4.531 \\
\hline $\mathbf{C u}$ & 3.056 & 21.428 & 8.833 & 26.423 & \pm 1.438 \\
\hline Mn & 10.66 & 46.46 & 22.18 & 74.412 & \pm 0.857 \\
\hline $\mathbf{P b}$ & 0.162 & 4.052 & 1.240 & 0.999 & \pm 0.167 \\
\hline Cd & 0.091 & 1.870 & 0.510 & 0.124 & \pm 0.059 \\
\hline As & BLD & BLD & - & - & - \\
\hline $\mathrm{Cr}$ & BLD & BLD & - & - & - \\
\hline
\end{tabular}

BLD., Below limit of detection

Table (2), showed that all the measured minerals were significantly varied among locations $(\mathrm{P} \geq 0.01)$. The magnitude of detected mineral levels expressed as a percentage of the mean has presented as coefficient of variability (C.V.). All the minerals showed variable values among locations reached 7.46, 9.36, 10.40,
$11.29,25.94$ and $45.55 \%$ of the corresponding overall location means for $\mathrm{Zn}, \mathrm{Mn}, \mathrm{Cu}, \mathrm{Fe}, \mathrm{Pb}$ and $\mathrm{Cd}$, respectively. Herbert and Miller-Ihli (1987) noticed that Iron and Manganese were highly variable, according to different botanical origin.

Table 2. Analysis of variance for $\mathrm{Fe}, \mathrm{Zn}, \mathrm{Cu}, \mathrm{Mn}, \mathrm{Pb}, \mathrm{Cd}, \mathrm{As}$ and $\mathrm{Cr}$ levels on pollen grains as affected by different locations:

\begin{tabular}{cccccccccc}
\hline $\begin{array}{c}\text { Source of } \\
\text { variation }\end{array}$ & d.f. & \multicolumn{7}{c}{ Mean squares } \\
\cline { 3 - 9 } & & $\mathrm{Fe}$ & $\mathrm{Zn}$ & $\mathrm{Cu}$ & $\mathrm{Mn}$ & $\mathrm{Pb}$ & $\mathrm{Cd}$ & $\mathrm{As}$ & $\mathrm{Cr}$ \\
\hline $\begin{array}{c}\text { Between } \\
\text { locations }\end{array}$ & 11 & $5212.7 * *$ & $2329.4 * *$ & $82.23 * *$ & $227.4 * *$ & $2.952 * *$ & $0.277 * *$ & - \\
\hline Error & 24 & 131.6 & 9.990 & 0.843 & 4.309 & 0.103 & 0.054 & - \\
\hline C.V. & & $11.29 \%$ & $7.461 \%$ & $10.40 \%$ & $9.36 \%$ & $25.94 \%$ & $45.55 \%$ & - \\
\hline
\end{tabular}

C.V.; Coefficient of variability.

* - Significant differences on a level of $\mathrm{p} \leq 0.05$ between location.

** - Highly Significant differences on a level of $\mathrm{p} \leq 0.01$ between location. 
Table (3), showed that the highest level of iron was detected from Etay- El baroud with a mean value of $167.36 \mathrm{ppm}$ and the lowest in Al-Muntazah with a mean value of $61.06 \mathrm{ppm}$.

Data presented in Table (3) revealed that, the highest levels of zinc (124.93 ppm) was in beebread samples collected from apiary in Abu-Hommoss, The lowest level was recorded from El-Tabya with a mean value of $21.95 \mathrm{ppm}$.

In general, iron (Fe) occurred at the highest concentrations in all tested samples followed by zink which is comply with Harmanescu et al., (2007a \&b); Popescu et al., (2010) and Dima et al. (2012) in Romania; Grembecka and Szefer (2013) in Poland; Fakhimzadeh and Lodenius (2000b) in Finland; Szczesna (2007)in Korea; Zhelyazkova et al. (2010) in China and Al Naggar et al. (2013) in Egypt.

The highest concentration of copper $(\mathrm{Cu})$ was detected from Kafr-El Dawar samples, with a mean value of $21.15 \mathrm{ppm}$ and the lowest from Al-Muntazah, which had $3.12 \mathrm{ppm}$ (Table, 3). The latter results are comparable with results for Copper which were reported by Fakhimzadeh and Lodenius (2000b); Harmanescu et al., 2007 and Silva et al. (2012) in
Brazil. Also, Al Naggar et al. (2013) recorded the highest levels of copper (22.28 and $24.18 \mathrm{ppm}$ ) while, the lowest (0.95 and $1.90 \mathrm{ppm})$ in Kafr-El Zayat and Kafr-El Sheikh, respectively. Szczesna (2007) reported that copper content ranged from 5.60 to $23.90 \mathrm{ppm}$ for the Poland samples, from 5.3 to $14.7 \mathrm{ppm}$ for the Korea samples and from 3.20 to $10.0 \mathrm{ppm}$ for the China samples with respective averages of 9.30, 10.10 and $7.50 \mathrm{ppm}$.

All the values obtained for copper contents in our study (Table, 3) were less than national accepted limits for this metal in similar products (200 $\mathrm{mg} / \mathrm{kg})$ (Ordinance no. 975, 1998), except the sample collected from Kafr El-Dawar (21.15 ppm) which exceeded the accepted limit. However, two samples collected from Al-Delengat and Abu-Hommos were greater than the Finland and Polish accepted level of copper for food (10.0 ppm) (Fakhimzadeh and Lodenius 2000b).

The pollen samples from Edko recorded the highest concentration of Manganese (44.87 ppm), while, the lowest value (13.02 ppm) was detected in samples from Kafr-El dawar (Table, 3).

Table 3. Means of $\mathrm{Fe}, \mathrm{Zn}, \mathrm{Cu}, \mathrm{Mn}, \mathrm{Pb}, \mathrm{Cd}$, As and $\mathrm{Cr}$ levels (mg/kg) in pollen samples of different locations from Alexandria and El-Behaira governorates:

\begin{tabular}{|c|c|c|c|c|c|c|c|c|}
\hline \multirow{2}{*}{ Location } & \multicolumn{8}{|c|}{ Minerals Levels ( mg.kg ${ }^{-1}$ ) } \\
\hline & $\mathrm{Fe}$ & $\mathrm{Zn}$ & $\mathrm{Cu}$ & $\mathrm{Mn}$ & $\mathrm{Pb}$ & $\mathrm{Cd}$ & As & $\mathrm{Cr}$ \\
\hline Edko & 118.67 & 42.367 & 5.120 & 44.879 & 0.966 & 0.145 & N.D & N.D \\
\hline Al-Delengat & 88.959 & 27.109 & 11.236 & 15.456 & 0.245 & 0.245 & N.D & N.D \\
\hline Abu Hommoss & 126.09 & 124.932 & 16.495 & 23.366 & 0.223 & N.D & N.D & N.D \\
\hline Etay El baroud & 167.362 & 39.871 & 6.285 & 25.830 & 0.948 & N.D & N.D & N.D \\
\hline Al-Muntazah & 61.064 & 35.069 & 3.125 & 17.638 & 0.231 & N.D & N.D & N.D \\
\hline Hosh eissa & 120.171 & 38.725 & 9.240 & 20.563 & 0.490 & 0.196 & N.D & N.D \\
\hline $\begin{array}{l}\text { Ezbet- } \\
\text { Mohsen }\end{array}$ & 81.304 & 40.962 & 5.033 & 25.646 & 1.183 & 0.477 & N.D & N.D \\
\hline Abis & 145.829 & 57.749 & 6.564 & 17.398 & 2.221 & 0.616 & N.D & N.D \\
\hline El-Tarh & 75.790 & 25.543 & 8.621 & 30.928 & 1.235 & N.D & N.D & N.D \\
\hline Khorshid & 116.618 & 26.685 & 5.539 & 18.424 & 1.926 & 0.120 & N.D & N.D \\
\hline Al-Tabia & 66.417 & 21.959 & 7.577 & 15.949 & 1.637 & 0.374 & N.D & N.D \\
\hline Kafr El-Dawar & 68.201 & 27.003 & 21.159 & 13.024 & 3.578 & 1.121 & N.D & N.D \\
\hline L.S.D 0.05 & 9.366 & 2.581 & 0.749 & 1.694 & 0.262 & 0.189 & N.D & N.D \\
\hline
\end{tabular}

N.D., not detected

Comparison between the present data and previous studies, indicated that, the concentration of Manganese in our samples were lower than those reported in pollen samples collected from South Korea and China with a mean value of 55.1 and $142.7 \mathrm{ppm}$, respectively (Szczesna, 2007). Manganese concentration in pollen have been reported in the range of 21 to $73 \mathrm{ppm}$ for industrial and Urban sites and from 68 to $110 \mathrm{ppm}$ in rural, non-industrialized sites from
Finland (Fakhimzadeh and Lodenius, 2000 a \&b). Dima et al. (2012) reported that Manganese levels in samples collected from urban sites (43 - $134 \mathrm{ppm})$ were higher than those values from rural sites $(21-52$ ppm) of Dambovita region in Romania. Zhelyazkova et al. (2010) recorded low values of Mn (7.28 and 8.52 ppm) in pollen samples from two regions in Bulgaria. Also, the values obtained in our study were comparable

Annals of Agric. Sci., Moshtohor, Vol. 54 (2) 2016. 
to those found in Poland (Grembecka and Szefer, 2013) which had a mean of $1.9 \mathrm{mg} / 100 \mathrm{~g}$.

The maximum content of lead $(\mathrm{Pb})$ was determined in beebread collected from Kafr El-Dawar with a mean value of $3.57 \mathrm{ppm}$, while the minimum content was from Abu-Hommoss (Table, 3). All these values exceeded the Polish permissible standard $(0.4-$ $0.5 \mathrm{ppm})$, the Finland accepted levels of lead in food (0.3 ppm) and the national accepted limits in similar products $(1.0 \mathrm{ppm})$ in Romania. On the other hand, the lower concentrations of lead were detected in 3 samples collected from Abu-Hommoss, Al-Muntazah and Al-Delengat with means of $0.22,0.23$ and 0.25 ppm, respectively, their values were below the prementioned permissible standards.

Some authors in Poland evaluated the degree of environmental pollution with lead on the basis of its detection in bees and their products, including pollen (Free et al., 1983; Konopacka et al., 1993; Jablonski et al., 1995 and Roman, 2009). They proved that lead amount in pollen load exceeded permissible standard and the highest levels were found in pollen coming from bee colonies situated very close to the road. Loper et al. (1980) conducted their research near the highway and recorded lead content in pollen on a level of 6 to $15 \mathrm{ppm}$. In addition, Conti and Botre (2001) proved relatively low lead concentration in pollen ranging from 0.020 to $0.332 \mathrm{ppm}$. On the other hand, Al- Naggar et al. (2013) found that lead levels in bee pollen collected during summer from bee hives in Elmehala El-kobra (10.53 ppm), Kafr-El Sheikh (13.85 ppm) and Kafr-El Zyat (10.13 ppm) considerably exceeded permissible standard, while, it was below the standard limit in Al- Fayoum (2.85 ppm).

The data obtained from the present study (Table, 3) revealed that, maximum concentration of cadmium was observed in samples collected from Kafr-El Dawar with mean value of $1.12 \mathrm{ppm}$, while, the minimum content was found in Khorshid $(0.120 \mathrm{ppm})$. On the other hand, only four samples collected from AboHommoss, Etay- El baroud, Al-Muntazah and El-Tarh were below detection limit.The average concentrations of this metal (Table, 1) in beebread $(0.51 \mathrm{ppm})$ significantly exceeded permissible standard. It was 10 times higher than the Polish and Trade Norms $(0.05$ ppm) and about 5 times greater than the Finland Norms and Kenya Bureau of Standard limits in food products (0.1 ppm).

Cadmium possesses the ability to accumulate, especially in soil. Due to the presence of cadmium in pesticides and mineral fertilizer, its concentration in rural regions may be significant (Winiarski, 1997). For that reason, in beebread samples coming from Kafr-El Dawar, the concentration of that element was observed higher than other analyzed samples (1.12 ppm).
Some authors in Poland have pointed out that the level of cadmium in most apiaries exceeded many times the acceptable norms (Lipinska and Zalewski, 1989; Migula and Kafel, 1992; Szczesna et al. 1993; Jablonski et al., 1995and Roman, 2007). They detected considerable cadmium concentration in pollen ranging from 0.03 to $0.50 \mathrm{ppm}$. The highest level $(0.181 \mathrm{ppm})$ was recorded in pollen loads collected in the apiary situated near the road.

A comparable values of cadmium in pollen was detected by Fakhimzadeh and Lodenius (2000a), which reported that mean values of cadmium was in the range of 0.03 to $1.20 \mathrm{ppm}$, it was above the Finland and Polish norms in $66 \%$ of tested samples. On the other hand, lower values of cadmium than obtained in our study were reported by Harmanescu et al. (2007a), it was $0.01 \mathrm{ppm}$. Also, Conti and Botre (2001) had recorded low values for the cadmium in bee pollen (0.015 to $0.09 \mathrm{ppm}$ ). However, Al Naggar et al. (2013) reported higher level for cadmium levels in pollen collected from Al-Fayoum (1.38 ppm) during summer, all the levels were higher than maximum admitted levels.

The high level of the detected metals in beebread samples from Kafr El-Dawwar, Abis Ezbet-Mohsen, and Khorshid may be attributed to existing of sources of pollution to the apiaries. These pollution sources were drainage of agriculture land $(<10 \mathrm{~m})$, Kafr ElDawwar Agriculture highway (20m), El-mansheia elgadeda Sewage treatment company $(300 \mathrm{~m})$ and Misr Co. for synthetic silk. ( $\geq 3 \mathrm{~km}$ ) near by Kafr El-Dawwar location and Abis bridge and highway $(1 \mathrm{~km})$, CairoAlex. Agriculture Highway $(\geq 1.5 \mathrm{~km})$, Abis drainage of agric. (100m) and Automatic slaughterhouse (300m) closed to Abis apiary location.The expected sources of pollution for the samples collected from apiaries in El Tabia, Al-Muntazah and El-Tarh is their location near Alex.-Fert for fertilizers Co, Abu-Qir-El tabia main street $(<1 \mathrm{~km})$ and Abu-Qir for fertilizers Co. $(<1 \mathrm{~km})$. Pollution of other districts could be due to their situation close to the Cairo-Alex Agriculture highway.

Table (4) demonstrates the daily intake value (DIM) of (Fe), zinc, cu, $\mathrm{Mn}$ and $\mathrm{Pb}$ which were calculated by taking the average value of metals in all beebread samples and considering that each person (assuming $70 \mathrm{~kg}$ of body weight) consumes approximately $36 \mathrm{~g}$ (about 4 teaspoons) of pollen per day. It is noted that all DIM values of the studied metals are below the recommended standers by WHO (1994) and USAPA, 2010 except for manganese which lies in the range of recommendation. Therefore, it could be concluded that there is no health hazard associated with consumption of bee pollen in the studied districts. 
Table 4. Estimated Daily Intake of Metals (DIM) through consumption of 36 gram (4 teaspoons) from bee pollen by human (Komosinska-Vassev et al., 2015):

\begin{tabular}{ccccc}
\hline Trace elements & $\begin{array}{c}\text { Average Conc. Of } \\
\text { pollen }(\boldsymbol{\mu g} / \mathbf{g})\end{array}$ & $\begin{array}{c}\text { Intake of metals by } \\
\text { human }(\mathbf{m g} / \mathbf{g})\end{array}$ & $\begin{array}{c}\text { RfD } \\
(\mathbf{m g} / \mathbf{d a y})\end{array}$ & References \\
\hline $\mathbf{F e}$ & 101.65 & 3.66 & $10-60$ & WHO 1994 \\
\hline $\mathbf{Z n}$ & 42.36 & 1.52 & 15 & WHO 1994 \\
\hline $\mathbf{C u}$ & 8.83 & 0.318 & $2-3$ & WHO 1994 \\
\hline $\mathbf{M n}$ & 22.18 & 0.798 & $0.5-5$ & WHO 1994 \\
\hline $\mathbf{P b}$ & 1.24 & 0.045 & 0.245 & WHO 1993 \\
\hline $\mathbf{C d}$ & 0.51 & 0.018 & 0.070 & US EPA 2010 \\
\hline
\end{tabular}

$\mathrm{RfD}$ is the oral dose for metal (mg/kg body weight/day)

Table (5), presented the correlation matrix between measured minerals pairs over the detected districts on bee pollen. Significant positive correlations were detected between cadmium and lead $(\mathrm{r}=0.387)$, cadmium and copper $(\mathrm{r}=0.442)$, lead and copper $(\mathrm{r}=$ $0.354)$ and zinc and iron $(r=0.041)$. Negative insignificant correlations were detected between cadmium and manganese $(\mathrm{r}=-0.219)$, cadmium and Iron $(r=-0.150)$, lead and each of zink, manganese and iron $(\mathrm{r}=-0.301,-0.253$ and -0.150$)$, respectively. Also, negative insignificant correlations were detected between manganese and copper $(\mathrm{r}=-$ $0.316)$ and between iron and copper $(r=-0.114)$.

Table 5. Correlation matrix between mineral apairs over the detected location for mineral content of pollen grains:

\begin{tabular}{|c|c|c|c|c|c|c|}
\hline & Cd & $\mathbf{P b}$ & $\mathbf{Z n}$ & Mn & $\mathrm{Fe}$ & $\mathrm{Cu}$ \\
\hline Cd & & $0.387 *$ & $0.163^{\text {n.s. }}$ & $-0.219^{\text {n.s. }}$ & $-0.150^{\text {n.s. }}$ & $0.442 * *$ \\
\hline $\mathbf{P b}$ & & & -0.301 & -0.253 & -0.179 & $0.354 *$ \\
\hline $\mathbf{Z n}$ & & & & 0.128 & $0.041 * *$ & 0.310 \\
\hline Mn & & & & & 0.220 & -0.316 \\
\hline $\mathbf{F e}$ & & & & & & -0.114 \\
\hline $\mathbf{C u}$ & & & & & & \\
\hline
\end{tabular}

\section{References}

Al-Naggar, Y.A.; Naiem, E.A.; Seif, A.I. and Mona, M.H. (2013). Honeybees and their products as a bio-indicator of environmental pollution with heavy metals. Mellifera, 13 (26): 10 - 20.

Anđelković, B.; Jevtić, G.; Mladenović, M.; Marković, J.; Petrović, M.and Nedić, N. (2012). Quality of pollen and honeybeebread collected in spring. Journal of Hygienic Engineering and Design, 1: $275-277$.

Bahreyni, R.; Mirhadi, S.A.; Javaheri, S.D. and Talebi, M. (2006). The survey on situation of heavy metals in honey, pollen and adult bees of Tehran province apiaries. Journal of Agricultural Science (University Of Tabriz), 15 (4): 247-252.

Campos, M. G. R.; Bogdanov, S.; Muradian, L. B.; Szezesna, T.; Mancebo, Y.; Frigerico, C. and Ferreira, F. (2008). Pollen composition and standardization of analytical methods. Journal of Apiculture Research and Bee World, 47(2): 156 163.
Celli, G. (1984). The honeybee as a pollution test insect. Apicoltore-Moderno (Italy). 75(3): 133-140.

Conti, M.E. (2000). Lazio region (central Italy) honey: a survey of mineral content and typical quality parameters. Food Control, 11 (6): 459-463.

Conti, M.E. and Botrè, F. (2001). Honeybees and their products as potential bioindicators of heavy metals contamination. Environmental Monitoring and Assessment, 69 (3): 267-282.

Cui, Y.J.; Zhu, Y.G.; Zhai, R.H.; Chen, D.Y.; Huang, Y.Z.; Qui, Y.and Liang, J.Z. (2004). Transfer of metals from soil to vegetables in an area near a smelter in Nanning, China. Environment International, 30: 785-791.

Demirezen, D. and Aksoy, A. (2005). Determination of heavy metals in bee honey using by inductively coupled plasma optical emission spectrometry (ICP-OES). G.U. Journal of Science, 18 (4): 569575.

Dima, G.; Popescu, I.V.; Dinu, S.; Niţescu, O. and Ştirbescu, R. (2012). Heavy metals in pollen samples collected from the Dambovita County 
analysed by Edxrf method. Rom. Journ. Phys., 57 $(9-10)$ : $1411-1416$.

Erbilir, F. and Erdoĝrul, Ö. (2005). Determination of heavy metals in honey in kahramanmaraş city, Turkey. Environmental Monitoring and Assessment, 109 (1-3): 181-187.

Fakhimzadeh, K. and Lodenius, M. (2000a). Heavy metals in Finnish honey, pollen and honeybees. Apiacta, 35 (2): 85-95.

Fakhimzadeh, K. and Lodenius, M. (2000b). Honey, pollen and bees as indicator of metal pollution. Acta Universitatis Carolinae Enviromentalica, 14: 13-20.

Formicki, G.; Gren, A.; Stawarz, R.; Zysk, B.and Gal, A. (2013). Metal content in honey, propolis, wax, and bee pollen and implications for metal pollution monitoring. Pol. J. Environ. Stud., 22 (1): 99 - 106.

Fredes, C., and Montenegro, G. (2006). Heavy metals and trace elements contents in Chilean honey. Ciencia e Investigacion AGRARIA, 33 (1): 50-58.

Free, J.B.; Williams, I.H.; Pinsent, R.J.F.; Townsend, A.; Basi, M.S.and Graham, C.L. (1983). Using foraging honeybees to sample an area for trace metals. Enviornment International, 9: 9-12.

Frías, I.; Rubio, C.; González-Iglesias, T.; Gutiérrez, Á.J.; González-Weller, D.and Hardisson, A. (2008). Metals in fresh honey from Tenerife island, Spain. Bulletin Of Environmental Contamination And Toxicology, 80 (1): 30-33.

Grembecka, M. and Szefer, P. (2013). Evaluation of honey and bee products quality based on their mineral composition using multivariate techniques. Environ Monit Assess., 185 (5): 4033 - 4047.

Harmanescu, M.; Popovici, D. and Gergen, I. (2007a). Heavy metals contents of bee's pollen from different locations of Romania. Lucr. Şt. Med. Vet. Timişoara, Vol. Xl: 253 - 260.

Harmanescu, M.; Popovici, D. and Gergen, I (2007b). Mineral micronutrients composition of bee's pollen. Journal of Agro Alimentary Processes and Technologies, Vol. E Xiii (1):175 -182.

Herbert, E.W. and Miller- Ihli, N.J. (1987). Seasonal variation of seven minerals in honeybee collected pollen. Am. Bee J., 127(5): 367 - 369.

Iannotti, O.; Mincigrucci, G.; Bricchi, E. and Frenguelli, G. (2012). Pollen viability as a bioindicator of air quality. Aerobiologia, 16 (3-4): 361-365.

Iqra A.; Sumera A.; Ahmed Z.; Muqaddas J.; Rashid S.; Muhammad K. S.; and Bushra M. (2015). Evaluating Insects as Bioindicators of Heavy Metal Contamination and Accumulation near Industrial Area of Gujrat, Pakistan. BioMed Research International Volume :11pp

Issac, R.A. and Kerber, J.D. (1971). Atomic absorption and flame photometry: techniques and uses in soil, plant and water analysis. In: Instrumental Methods for Analysis of Soil and Plant Tissue. Soil Science Sosciety of America-Agronomy Society of America, Inc, Madison, Wisconsin, 17-37.

Jablonski, B.; Koltowski, Z.; Marcinkowski, J.; RybakChmielewska, H.; Szczesna, T. and Warakomska, Z. (1995). Contamination of nectar, honey and pollen collected from roadside plants. Pszczelnicze Zeszyty Naukowe, 39(2): 129-144. [In Polish; English abstract].

Jones, K.C. (1987). Honey as an indicator of heavy metal contamination. Water, Air, and Soil Pollution, 33 (1): 179-189.

Kenya Bureau Standards (1996). Specifications for honey (Second Edition). KS 0.5-344

Komosinska-Vassev, K.; Olczyk, P.; Kafmierczak, J.; Mencner, L. and Olczyk, K. (2015). Bee pollen: chemical composition and therapeutic application. Evidence-Based Complementary And Alternative Medicine (eCAM), V. 2015, Article ID 297425, 6 pages. http://dx.doi.org/10.1155/2015/297425.

Konopacka, Z.; Pohorecka, K.; Syrocka, K. and Chaber, J. (1993). The contents of cadmium, lead, nitrates and nitrites in pollen loads collected from different sites in vicinity of Pulawy. Pszczel. Zesz. Nauk, 37: 181-187. [In Polish; English abstract].

Lambert, O.; Piroux, M.; Puyo, S.; Thorin, C.; Larhantec, M.; Delbac, F. and Pouliquen, $\mathrm{H}$. (2012). Bees, honey and pollen as sentinels for lead environmental contamination. Environmental Pollution, 170: 254 - 259.

Loper, G.M.; Standifer, L.N.; Thompson, M.J. and Gillian, M. (1980). Biochemistry and microbiology of bee-collected almond (prunus dulcis) pollen and beebread. I. Fatty acids, sterols, vitamins and minerals. Apidologie, 11: 63-73. (Cited from Szczesna, 2007a).

Lazor, P.; Tomáš, J.; Tóth, T.; Tóth, J. and Čéryová, S. (2012). Monitoring of air pollution and atmospheric deposition of heavy metals by analysis of honey. Journal of Microbiology Biotechnology and Food Sciences (JMBFS) , 1 (4): 522 - 533.

Leita, L.; Muhlbachova, G.; Cesco, S.; Barbattini, R. and Mondini, C. (1996). Investigation of the use of honeybees and honeybee products to assess heavy metals contamination. Environmental Monitoring and Assessment, 43: 1-9.

Lipinska, J. and Zalwski, W. (1989). The content of microelements and harmful elements in bee products from Poland. Apicultral Scientific Exercise Books, 33, 113, 1989 [In Polish].

Marco, G.; Canuti, L.; Impei, S.; Leonardi, D.and Canini, A. (2012). Nutraceutical properties of honey and pollen produced in a natural park. Agricultural Sciences, 3 (2): 187 - 200. 
Mbiri, A.; Onditi, A.; Oyaro, N. and Murago, E. (2011). Determination of essential and heavy metals in Kenyan honey by atomic absorption and emission spectroscopy. JAGST, 13 (1): 107 - 115.

Migula, P. and Kafel, A. (1992). Change the bee's products quality from contaminated regions. Polish beekeeping, 3: 15. [In Polish].

Morgano, M.A.; Martins, M.C.T.; Rabonato, L.C.; Milani, R.F.; Yotsuyanagi, K. and RodriguezAmaya, D.B. (2010). Inorganic contaminants in bee pollen from Southeastern Brazil. J. Agric. Food Chem., 58 (11): 6876 - 6883.

Moroń, D.; Grzes', I.M.; Skorka, P.; Szentgyorgyi, H.; Laskowski, R.; Simon, G.P. and. Woyciechowski, M (2011). Abundance and diversity of wild bees along gradients of heavy metal pollution. Journal of Applied Ecology, 49 (1): 118 - 125.

Moussa M. I. and Abdelkhalek, A. M. (2007). Meterological analysis for black cloud (Episodes) formation and its monitoring by remote sensing. Journal of Applied Sciences Research 3(2): 147 154.

Mstat-C Package (1989). A micro-computer program for the design, management and analysis of Agronomic Research Experiments: Version 4.0, Michigan state university.

Ordinance no. 975 (1998). Maximum limits accepted for heavy metal in foods. Excerpt from Romanian Ministry of Public health Ordinance no 975/1998.

Osman W. , El-Samad L. M, Mokhamer E. H., ElTouhamy A, Shonouda M. (2015). Ecological, morphological, and histological studies on Blaps polycresta (Coleoptera: Tenebrionidae) as biomonitors of cadmium soil pollution. Environ. Sci. Pollut. Res. Int. (18):14-15.

Perugini, M.; Manera, M.; Grotta, L.; Abete, M.C.; Tarasco, R. and M, Amorena (2011). Heavy metal $(\mathrm{Hg}, \mathrm{Cr}, \mathrm{Cd}$, and $\mathrm{Pb})$ contamination in urban areas and wildlife reserves: honeybees as bioindicators. Biological Trace Element Research. 140 (2): 170 176.

Popescu, I.V.; Dima, G. and Dinu, S. (2010). The content of heavy metals in pollen from Dambovita region. Journal of Science and Arts, 1 (12): 171 174.

Przybyłowski, P. and Wilczyńska, A. (2001). Honey as an environmental marker. Food Chemistry, 74 (3): 289-291.

Rashed, M.N.; El- Haty, M.T.A. and Mohamed, S.M. (2009). Bee honey as environmental indicator for pollution with heavy metals. Toxicological And Environmental Chemistry, 91: 389 - 403.

Roman, A. (2007). Content of some trace elements in fresh honeybee pollen. Pol. J. Food Nutr. Sci., 57 (4) $\mathrm{C}: 475-478$.
(2009). Concentration of chosen trace elements of toxic properties in bee pollen loads. Polish Journal of Environmental Studies, 18 (2): $265-272$.

(2010). Level of copper, selenium, lead, and cadmium in forager bees. Polish Journal of Environmental Studies, 19 (3): 663 - 669.

Shahir, K.W. and Taher, E.J. (2012). Contamination of bee honey with $\mathrm{Cd}$ and $\mathrm{Pb}$. Iraqi Journal of Agricultural Sciences, 43 (5): 63 - 68.

Silva, A.S.; Araújo, S.B.; Souza, D.C. and Silva, F.A. (2012). Study of the $\mathrm{Cu}, \mathrm{Mn}, \mathrm{Pb}$ and $\mathrm{Zn}$ dynamics in soil, plants and bee pollen from the region of Teresina (Pi), Brazil. Anais Da Academia Brasileira De Ciencias , 84 (4): 881 - 889.

Szczêsna, T. (2007). Concentration of selected elements in honeybee-collected pollen. Journal of Apicultural Science, 51 (1): 5-13.

Szczêsna, T.; Rybak-Chmielewsk, H.and Arciuch, H. (1993). Application of anodic stripping voltammetry to determination of $\mathrm{Cd}, \mathrm{Pb}$ and $\mathrm{Cu}$ in pollen loads. Apicultural Scientific Exercise Books, 37, 171 [in polish].

U.S. Environmental Protection Agency [US EPA] (2010) Integrated Risk Information System. Available at: http://cfpub.epa.gov/ncea/iris/compare.cfm. [Accessed jan. 08, 2010].

Vincevica-Gaile, Z.; Klavins, M.; Udovica, V. and Viksna, A. (2012). Potentially toxic metals in honey from Latvia: is there connection with botanical origin? In Book: recent researches in environment, energy systems and sustainability; 158 - 163.

Winiarski, A. (1997). The artificial fertilizers as potential threat for the man health and the environment the chemical danger in agriculture. The Monograph of Village Medicine Institute, Lublin [In polish].

World Health Organization [WHO] (1994). Health guidline for the use of wastewater in agriculture and aquaculture. Report of WHO scince group, world health organization, Geneva, Switzerland. Tech. Rep. Sci. 778:10.

Youssef, A.M.; Farag, R.S.; Ewies, M.A. and ElShakaa, S.M.A. (1978). Chemical studies on pollen collected by honeybees in Giza region, Egypt. J. Apic. Res., 17(3): $110-113$.

Zhelyazkova, I.; Atanasova, S.; Barakova, V. and Mihaylova, G. (2010). Content of heavy metals and metalloids in bees and bee products from areas with different degree of anthropogenic impact. Agricultural Science and Technology, 3 (1): 136 142. 


\title{
تقديرمتوى بعض المعادن في خبز النحل من مناطق مختلفة من محافظتى الاسكندرية و البحيرة
}

\author{
محمد عصام محمد اسماعيل - ماجدة حسن على سالم - محمد صلاح الدين محجوب - نبيل سيد سالم البربرى \\ قسم علم الحشرات التطبيقى - كلية الزراعة - جامعة الاسكندرية
}

تم فى هذا البحث تقدير مستوى بعض المعادن في عينات من خبز النحل نم جمعها في الفتزة من شهر مارس إلى سبتمبر 2013 من 12 منحل في

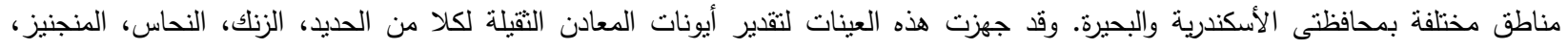

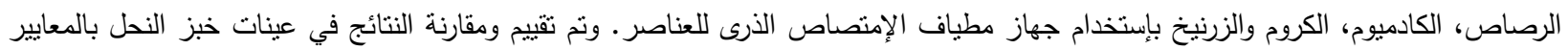

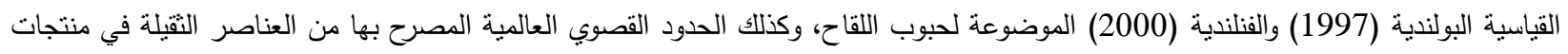

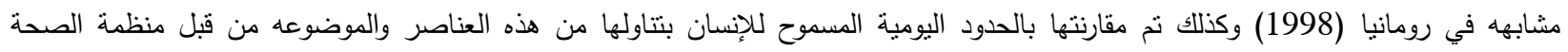

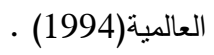

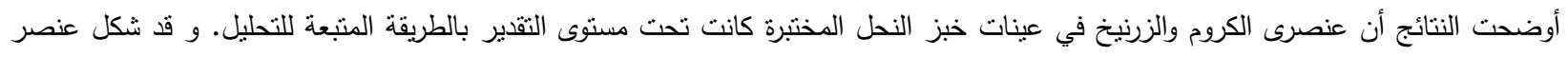

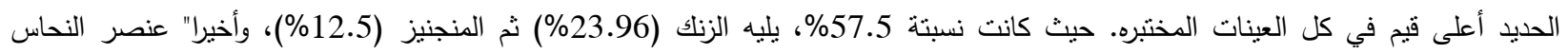

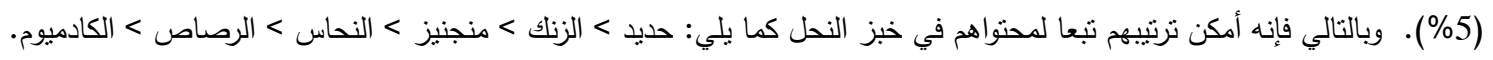

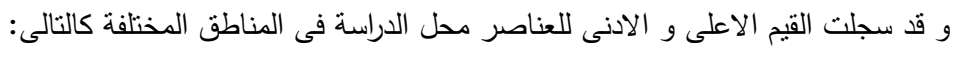

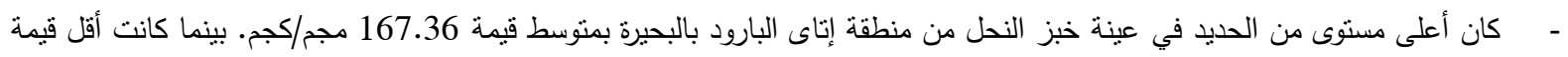

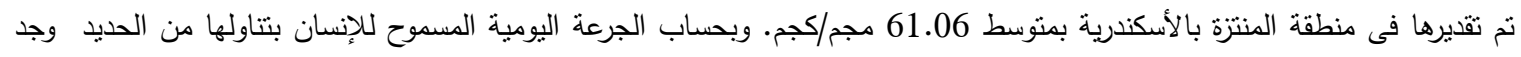

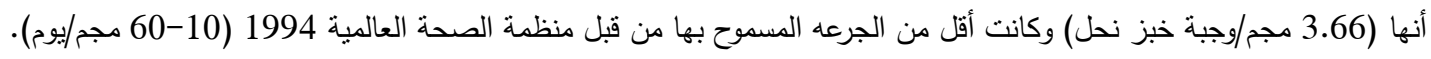

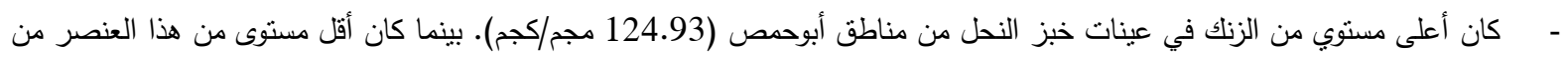

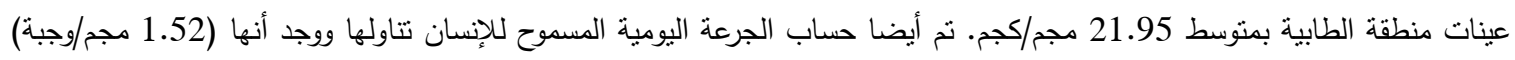

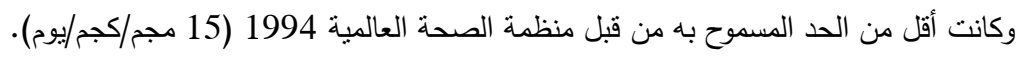

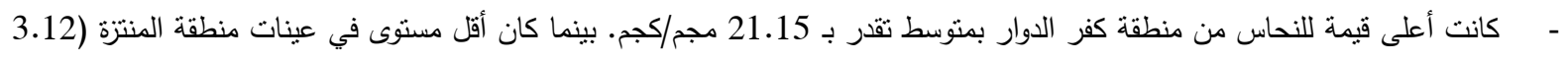

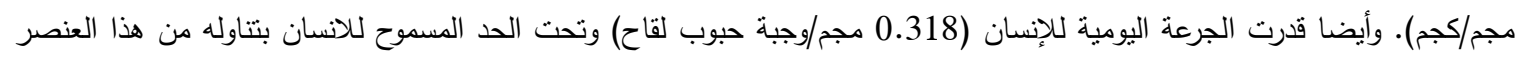

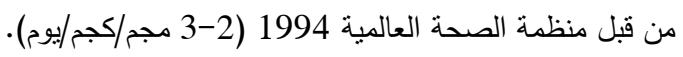

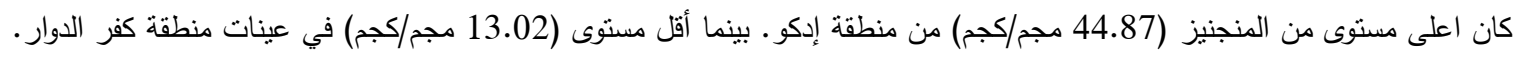

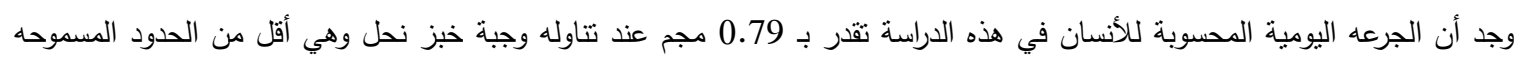

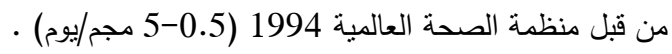

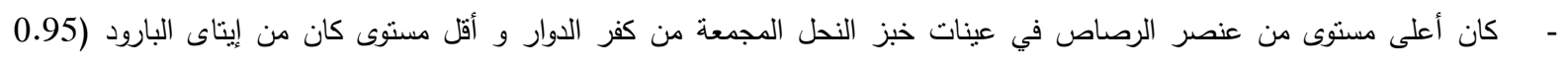

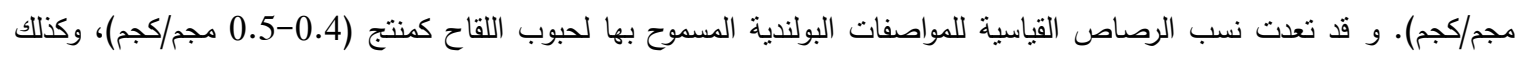

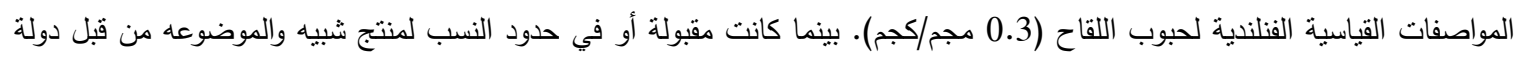

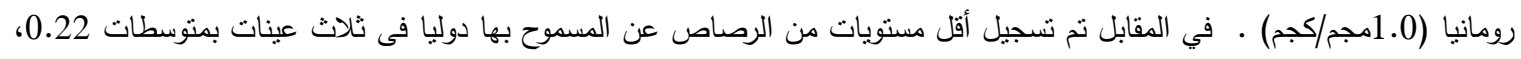

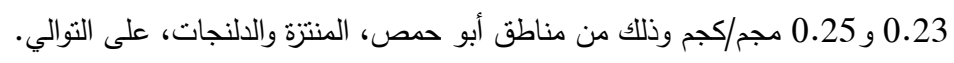

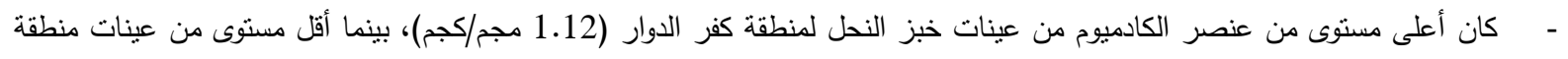

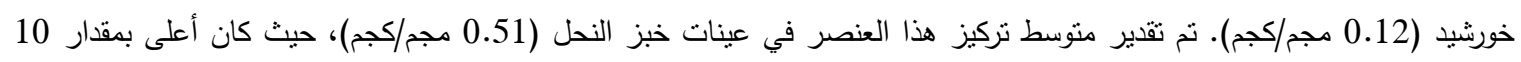

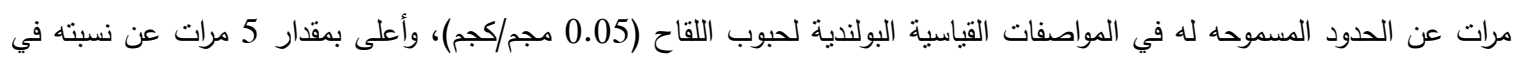

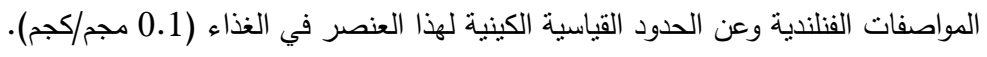

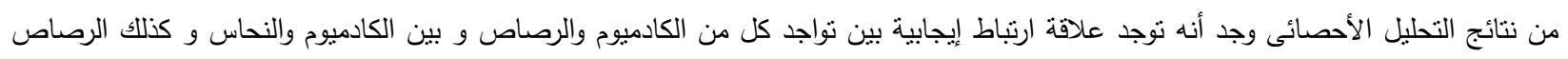

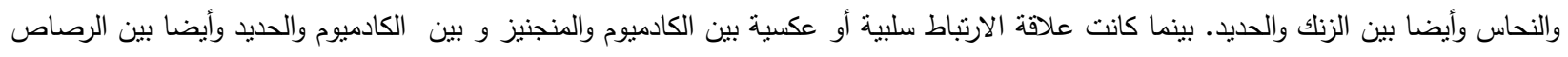
وكلا من الزنك، المنجنيز والحديد. 
